Article

\title{
Lacticaseibacillus rhamnosus GG Survival and Quality Parameters in Kefir Produced from Kefir Grains and Natural Kefir Starter Culture
}

\author{
Amin Yousefvand ${ }^{1,2, *}$, Xin Huang ${ }^{3}{ }^{(0)}$, Mehdi Zarei ${ }^{1}$ and Per Erik Joakim Saris ${ }^{2}$ \\ 1 Department of Food Hygiene, Faculty of Veterinary Medicine, Shahid Chamran University of Ahvaz, \\ P.O. Box 6135783-151, Ahvaz 61, Iran; zarei@scu.ac.ir \\ 2 Department of Microbiology, Faculty of Agriculture and Forestry, University of Helsinki, Viikinkaari 9, \\ P.O. Box 56, FI-00014 Helsinki, Finland; per.saris@helsinki.fi \\ 3 Department of Food and Nutrition, Faculty of Agriculture and Forestry, University of Helsinki, \\ Agnes Sjöberginkatu 2, P.O. Box 66, FI-00014 Helsinki, Finland; xin.huang@helsinki.fi \\ * Correspondence: amin.yousefvand@helsinki.fi; Tel.: +358-468492855
}

Citation: Yousefvand, A.; Huang, X.; Zarei, M.; Saris, P.E.J. Lacticaseibacillus rhamnosus GG Survival and Quality Parameters in Kefir Produced from Kefir Grains and Natural Kefir Starter Culture. Foods 2022, 11, 523. https:// doi.org/10.3390/foods 11040523

Academic Editor: Andrea

Gomez-Zavaglia

Received: 12 January 2022

Accepted: 9 February 2022

Published: 11 February 2022

Publisher's Note: MDPI stays neutral with regard to jurisdictional claims in published maps and institutional affiliations.

Copyright: (C) 2022 by the authors. Licensee MDPI, Basel, Switzerland. This article is an open access article distributed under the terms and conditions of the Creative Commons Attribution (CC BY) license (https:// creativecommons.org/licenses/by/ $4.0 /)$.

\begin{abstract}
The study aimed to determine the effect of starter cultures (kefir grains and natural kefir starter culture without grains) on Lacticaseibacillus rhamnosus GG (LGG) survival and on the quality characteristics of kefir. To this end, the viability of probiotic L. rhamnosus GG strain and the rheological properties and quality parameters of kefir beverages were tested during storage over 21 days at $4{ }^{\circ} \mathrm{C}$. The final LGG counts were 7.71 and $7.55 \log \mathrm{cfu} / \mathrm{mL}$ in natural kefir starter culture and kefir grain, respectively. When prepared with probiotic bacteria, the syneresis values of kefir prepared using natural kefir starter culture was significantly lower $(p<0.05)$ than that of kefir made using grains. However, the viscosity indices, hysteresis loop, and dynamic moduli were similar between kefir made with natural kefir starter culture and other kefir formulations $(p>0.05)$. Moreover, all samples showed shear-thinning behavior. The flavor scores for kefir prepared using natural kefir starter culture were significantly higher than for the other samples $(p<0.05)$, but overall acceptability was similar at the 10-day assessment across both starters (with and without grain) after the addition of probiotic bacteria $(p>0.05)$. Overall, the results indicate that natural kefir starter culture could be a potential probiotic carrier.
\end{abstract}

Keywords: probiotic; kefir; natural kefir starter culture; kefir grain; viscosity

\section{Introduction}

Kefir is an acidic-alcoholic fermented dairy beverage with unique attributes such as a slightly sour and yeasty flavor, and a viscous and creamy density. Kefir grains are white to yellowish, irregularly shaped cauliflower-like grains that are traditionally used to manufacture kefir $[1,2]$. There is a consortium of many bacteria from Lacticaseibacillus, Lactobacillus, Lactococcus, Leuconostoc, and Streptococcus genera while yeast genera contain Kluyveromyces, Candida, Saccharomyces, and Pichia embedded in a resilient water-soluble exopolysaccharide (EPS) matrix, known as kefiran, which produces lactic acid and alcohol, respectively [3-5]. The consumption of kefir has many advantages, including alleviation of lactose intolerance symptoms [6], deterrence of pathogenic bacteria [5], as well as antiinflammatory [7] and antioxidant activity [8]. It has been reported that kefiran in kefir acts as the delivery mechanism of probiotic organisms. Accordingly, kefir has potential to carry probiotic bacteria [9]. It was recently shown that lactic acid bacteria (LAB) counts in kefir were higher from kefir grains than commercial kefir starter culture, suggesting that the commercial starter is not capable of promoting optimal LAB survival [10]. More recently, some commercial kefir starter cultures are existent for industrial production, but they often contain limited yeast species [11]. Due to the lack of reliable population of microorganisms 
in commercial kefir starter cultures, a remarkable diminution in sensory properties is usually observed. In fact, fermented dairy products develop their unique organoleptic and functional attributes as result from the metabolic activity of the multispecies microflora, where more than one type of interaction may occur concomitantly [12]. Kefir can also be manufactured from natural kefir starter culture, which is initially captured from kefir grains with the same microbial composition. Its use as a starter culture and potential LAB carrier for industrial applications is much easier than kefir grains.

Currently, the consumption of probiotic-containing fermented dairy products is accepted among the general public. Probiotic bacteria are defined as live microorganisms, which, when administered in adequate amounts, provide health benefits to the host [13]. For example, consumption of probiotic organisms has been associated with the alleviation of lactose intolerance symptoms, improvement of stomach and colon health, modulation of the host immune system, inhibition of pathogenic bacteria, as well as anti-inflammatory, antidiabetic, and anticarcinogenic properties [14-16]. Dairy products with probiotic claims should maintain at least $10^{7} \mathrm{cfu} / \mathrm{mL}$ of viable cells as a satisfactory level [17].

The majority of probiotic bacteria used in the food industry are LAB, mostly lactobacilli species [18]. Among them, the Lacticaseibacillus rhamnosus GG (LGG) strain has been extensively studied. It has been established as a non-spore-forming, non-motile, facultative heterofermentative, anaerobic, and catalase-negative bacterium [19,20]. Moreover, some studies have demonstrated that the probiotic LGG strain can persist in an acidic environment, for example while passing through the gastrointestinal tract, which represents a harsh environment for probiotics [15,21].

Many health benefits have been attributed to the LGG strain, including preventing and treating of gastrointestinal infections and diarrhea. It also has antimicrobial properties. Therefore, several research studies have already been conducted to develop fermented and non-fermented products enriched with LGG, such as yoghurt, buttermilk, milk, fruit drinks, salad dressing, dry sausages, and cheese [22-25]. The aim of this study was to evaluate the viability of probiotic LGG in kefir products made with kefir grains and natural kefir starter cultures without grain. Moreover, quality characteristics namely organoleptic, syneresis, chemical, and rheological properties of kefir products from kefir grain and natural kefir starter culture with added LGG were compared to those of a control product over 21 days of storage at $4{ }^{\circ} \mathrm{C}$.

\section{Materials and Methods}

\subsection{Preparation of Kefir Samples}

Kefir was manufactured according to the methods of Kök-Taş et al. [11] and Irigoyen et al. [26]. Commercial full-fat ultra-high temperature (UHT) milk (3.6 g/100 g of fat, $12.8 \mathrm{~g} / 100 \mathrm{~g}$ of total solids (TS) content, and $\mathrm{pH}$ of 6.67) was used. Kefir grains (KG) were purchased from prebiotic company (Tehran, Iran). The grains were inoculated in UHT milk at room temperature and kept for short periods; the medium was replaced with fresh UHT milk daily to maintain the grains' viability. The grains were activated to obtain high amounts of the kefir grain biomass. Kefir grains and natural kefir starter culture (KS) were used to ferment milk for kefir production. Natural kefir starter culture was obtained from kefir grains by straining the grains using a cloth sieve after fermentation at $28^{\circ} \mathrm{C}$ for approximately $20 \mathrm{~h}$; the final fermentation $\mathrm{pH}$ was 4.6 . Fermentation time $(20 \mathrm{~h})$ was the same for KG and KS. The inoculation rate of the culture was selected after preliminary sensory studies. Briefly, a sensory panel of 12 semi-trained and experienced panelists tested kefir samples cultured with different inoculation rates $(2,3$, and $5 \%)$, and evaluated them according to overall presentation (taste, smell, texture, and appearance). The optimal inoculation rates were $2 \%$ for KG (wt/vol) and $3 \%$ for KS (wt/vol).

\subsection{Manufacturing of Kefir Beverages}

Before the kefir preparation, Lacticaseibacillus rhamnosus GG strain (LGG; ATCC 53103) [27] was cultured in de Man, Rogosa, Sharpe (MRS; Oxoid, Basingstok, Hampshire, UK) medium 
at $37^{\circ} \mathrm{C}$ for $24 \mathrm{~h}$ under anaerobic conditions. Following incubation, $50 \mu \mathrm{L}$ of probiotic culture was sub-cultured in plastic tubes containing $50 \mathrm{~mL}$ of MRS broth, which were incubated at $37{ }^{\circ} \mathrm{C}$ overnight under anaerobic conditions. Next, the probiotic culture biomass was harvested by centrifugation at $4000 \times g$ for $10 \mathrm{~min}$ at $20^{\circ} \mathrm{C}$, and washed twice with sterilized standard saline solution. Finally, the harvested cells were resuspended in $10 \mathrm{~mL}$ of UHT milk and used as a LGG culture to produce kefirs. Four different kefir batches were prepared: KG (kefir produced from kefir grains), KG-LGG (kefir made from kefir grains, with the addition of LGG), KS (kefir produced from natural kefir starter culture), and KS-LGG (kefir produced from natural kefir starter culture, with the addition of LGG). All batches were incubated at $28^{\circ} \mathrm{C}$ for $20 \mathrm{~h}$ (Figure 1). Kefir samples containing the LGG strain were prepared using $1 \%$ probiotic LGG with $2 \% \mathrm{KG}$ and $3 \% \mathrm{KS}$. All samples were filtered by a cloth sieve to filter out the grains. After kefir production, the samples were kept for 21 days at $4{ }^{\circ} \mathrm{C}$. Probiotic viability and physicochemical properties were analyzed after 1,7, 14, and 21 days of storage.

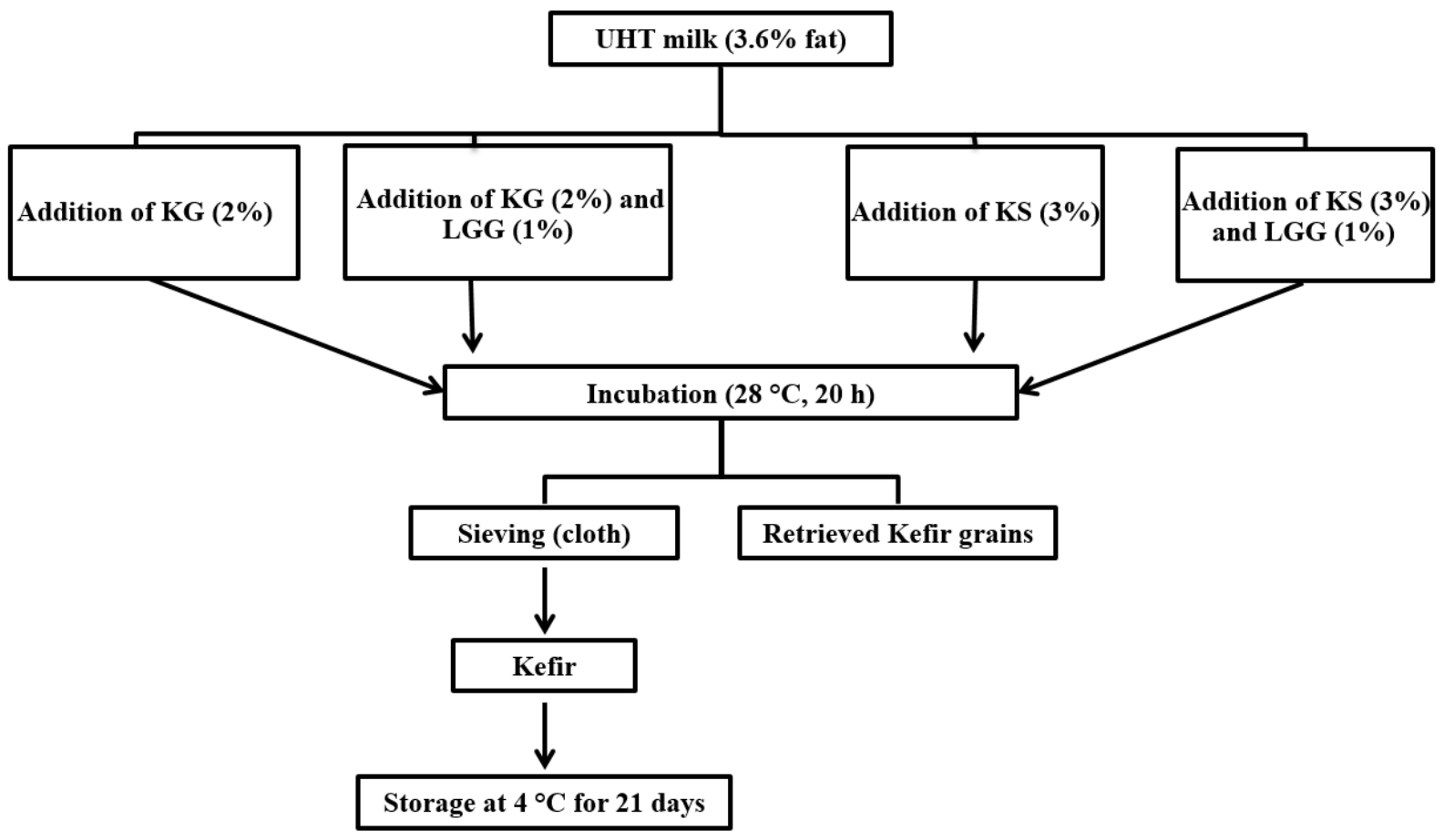

Figure 1. Manufacturing flowchart of different formulations of kefir. KG = kefir produced from kefir grains; KS = kefir produced from natural kefir starter culture; LGG = Lacticaseibacillus rhamnosus GG.

\subsection{Physicochemical Analysis of Kefir: $p H$, Total Titratable Acidity (TTA), Syneresis}

$\mathrm{pH}$ values of the kefir were determined using a $\mathrm{pH}$ meter (Thermo Orion Model$420 \mathrm{~A}^{\prime}$ ). In addition, TTA was measured by the AOAC official method [28]. The syneresis values of the kefir samples were determined as recommended by Aryana [29]. Briefly, $100 \mathrm{~g}$ of each kefir batch was weighted on a fine mesh screen $(14 \mu \mathrm{m})$ placed on top of a funnel. Syneresis is expressed as the amount of whey separated from the samples under the force of gravity at room temperature after $2 \mathrm{~h}$ of drainage into a flask of known weight, divided by the initial kefir mass.

\subsection{Enumeration of $L G G$}

First, $1.0 \mathrm{~mL}$ of each sample was diluted with $9 \mathrm{~mL}$ of physiological saline solution. Samples were then serially diluted; using the spread-plate technique in agar made of modified MRS (mMRS $\left(\mathrm{g} \mathrm{L}^{-1}\right)$ : peptone (Fisher Scientific, Janssen-Pharmaceuticalaan, Belgium), 10; yeast extract (Acros Organics, NJ, USA), 4; $\mathrm{K}_{2} \mathrm{HPO}_{4}$ (Merck, Darmstadt, Germany), 2; $\mathrm{NaCH} 3 \mathrm{CO}_{2} \cdot 3 \mathrm{H}_{2} \mathrm{O}$ (Oxoid, Hampshire, UK)), 5; triammonium citrate (Fisher Scientific, Loughborough, UK), $2 ; \mathrm{MgSO}_{4} \cdot 7 \mathrm{H}_{2} \mathrm{O}$ (J.T.Baker, Deventer, The Netherlands), 
0.2; $\mathrm{MnSO}_{4} \cdot \mathrm{H}_{2} \mathrm{O}$ (Merck, Darmstadt, Germany), 0.05) supplemented with $1 \%$ (wt/vol) lactose and $50 \mu \mathrm{g} / \mathrm{mL}$ of bromocresol purple (BCP), the plates were incubated at $37^{\circ} \mathrm{C}$ for $24-48 \mathrm{~h}$ in an anaerobic jar. During incubation, lactose-positive bacteria produce lactic acid by the fermentation of lactose, which lowers the $\mathrm{pH}$ of the media, changing the color of BCP from purple to yellow, whereas lactose negative bacteria grow as small colonies utilizing peptone and yeast extract for growth without production of lactic acid explaining why the colonies remain purple.

Since LGG does not utilize lactose, colonies without acid production did not change color; these were streaked onto MRS agar plates to obtain pure cultures for identification of LGG colonies by strain-specific PCR. For each amplification reaction, a positive control (L. rhamnosus GG strain (ATCC 53103) and a negative control (double distilled water) were included. Next, the lactose-negative colonies (presumptive LGG strains) were used as templates in colony PCR using primers specific to L. rhamnosus GG in Eppendorf Mastercycler (Hamburg, Germany) for the amplification of a fragment containing hypothetical conserved protein gene LGG_00154 using 5'-CGCCCTTAACAGCAGTCTTC-3' and $5^{\prime}$-GCCCTCCGTATGCTTAAACC-3' sequences as forward and reverse primers, respectively [27], yielding a 757-bp product. Phusion high-fidelity DNA polymerase (Thermo Fisher Scientific, Waltham, MA, USA) was used for PCR amplification. PCR was carried out in the final volume of $25 \mu \mathrm{L}$ containing $20 \mathrm{pmol}$ in each primer, Phusion HF buffer, $0.2 \mathrm{mM}$ of deoxynucleotide triphosphates, $0.5 \mathrm{U}$ of Phusion DNA polymerase, and cells from a single colony as the template under the following conditions: $30 \mathrm{~s}$ at $98^{\circ} \mathrm{C}$ as an initial denaturation step, followed by 35 cycles of denaturation at $98^{\circ} \mathrm{C}$ for $10 \mathrm{~s}$, annealing at $60{ }^{\circ} \mathrm{C}$ for $30 \mathrm{~s}$, and extension at $72{ }^{\circ} \mathrm{C}$ for $30 \mathrm{~s}$, and a final extension step of $72{ }^{\circ} \mathrm{C}$ for $5 \mathrm{~min}$. The amplification products $(5 \mu \mathrm{L})$ were then separated by electrophoresis in $0.5 \mathrm{mg} / \mathrm{mL}$ ethidium bromide-stained $1 \%(\mathrm{wt} / \mathrm{vol})$ agarose gel, and the DNA was visualized by a ChemiDoc MP imaging system (Bio-Rad, Hercules, CA, USA). The size markers used were 100-bp GeneRuler DNA ladders (Thermo Fisher Scientific). Colonies resulting in an amplified fragment of a size corresponding to the expected 757-bp fragment were regarded as LGG strains [30].

\subsection{Sensory Analysis of Kefir}

The assessment of flavor, body, texture, color, appearance, and overall acceptability of all kefir samples was performed by a panel of 15 semi-trained and experienced members (students, academic staff and faculty members at the University of Helsinki, Helsinki, Finland). Kefir samples were served to the panelists in transparent glass cups bearing 3-digit random codes. Each sample was scored individually on a 5-point hedonic scale ranging from 1 (dislike extremely) to 5 (like extremely) on the tenth day of storage. Evaluators were instructed to rinse their mouths with drinking water before tasting each sample.

\subsection{Determination of Apparent Viscosity and Gel Structure of Kefir}

The viscosities of the kefir samples were measured with a HAAKE MARS 40 rheometer (Thermo Scientific, Germany) with a parallel-plate (diameter $35 \mathrm{~mm}$ ) measuring system. The flow behavior was determined by a rotational measurement in which the shear rate was first increased in a stepwise manner from 0.3 to $3001 / \mathrm{s}$ (20 steps), then decreased from 300 to $0.31 / \mathrm{s}$ (20 steps). All viscosities were measured at $4{ }^{\circ} \mathrm{C}$ (the storage temperature of the kefir). The system was stabilized for $2 \mathrm{~min}$ before analysis. The apparent viscosities of the kefir were reported at a shear rate of $23.51 / \mathrm{s}$ when rotation shear rate increased from 0.3 to 300 1/s. Hysteresis loop area, which indicates the structural degradation, was reported by calculating the change in area of the flow profile between 0.3 to $3001 / \mathrm{s}$ and 300 to 0.3 1/s, using RheoWin Measuring and Evaluation Software. To demonstrate the viscoelastic properties of the kefir during storage, a frequency sweep was conducted from 0.1 to $10 \mathrm{~Hz}$ using oscillatory measurement with a strain that was selected from the linear viscoelastic range. The $\mathrm{G}^{\prime}$ (storage modulus) and $\mathrm{G}^{\prime \prime}$ (loss modulus) were reported at a 
frequency of $1.46 \mathrm{~Hz}$. Two biological replicates were analyzed for each timepoint, and each replicate was measured twice for all tests.

\subsection{Statistical Analysis}

All physicochemical analyses and microbial enumerations were conducted in triplicates. The data obtained for kefir's physicochemical, microbial, and organoleptic evaluation were analyzed with ANOVA using the General Linear Model procedure, reported as mean \pm standard deviations. Tukey's test was used to compare the means; significant differences were estimated based on a $p<0.05$. All statistical analyses were carried out using Minitab 16 program (Minitab Inc., State College, PA, USA).

\section{Results and Discussion}

\subsection{PH and TTA of Kefir}

The $\mathrm{pH}$ values of the kefir samples were measured after 1,7,14, and 21 days of storage at $4{ }^{\circ} \mathrm{C}$. The index of $\mathrm{pH}$ of all kefir samples ranged between 4.49 and 4.53 on day 1 ; these values decreased throughout the storage period, as also reported in other fermented milk products such as yoghurt [31,32]. $\mathrm{pH}$ values of KG varied from 4.53 to 4.32 , and from 4.49 to 4.34 in KS throughout the duration of storage time (Figure 2A). These values were higher than those reported by Kök-Taş et al. [11], who noted $\mathrm{pH}$ values of $4.47-4.29$ for KG, and $4.50-4.37$ for KS during 21 days of storage at $4{ }^{\circ} \mathrm{C}$.

The mean $\mathrm{pH}$ values were similar between kefir cultures with and without probiotic strain $(p>0.05)$ (Figure 2A), in accordance with results reported by Mitra and Ghosh [33], who also observed a slight but insignificant decrease in $\mathrm{pH}$ values in kefir samples containing LGG. During the storage period, $\mathrm{pH}$ values of the kefir samples made with natural kefir starter culture and the added probiotic LGG strain were significantly different $(p<0.05)$ from those without the added LGG probiotic. Notably, the $\mathrm{pH}$ of kefir products is correlated with their acidity $[2,11,33]$. Lactic acid is the most widespread acid produced by probiotic bacteria [31]. In this study, the lactic acid content (\%) of KG and KS samples varied from 0.88 to 0.92 , and from 0.87 to 0.90 , respectively, during the 21 days of storage time (Figure 2B). In a similar study, Kök-Taş et al. [11] found the lactic acid content of KG and KS samples to range from 0.89 to 0.92 , and from 0.83 to 0.89 , respectively, during 21 days of storage at $4{ }^{\circ} \mathrm{C}$. These slight differences may occur due to the yeast content limiting the propagation of LAB [34]. The acidity of the kefir grains was similar to that of the natural kefir starter culture with LGG probiotic strain $(p>0.05)$ (Figure 2B). The increased acidity in KG-LGG and KS-LGG compared to KG and KS may be assigned to metabolism of facultatively heterofermentative in LGG that transforms hexoses into L (+)-lactic acid through the Embden-Meyerhof pathway, as previously described [20].

\subsection{Syneresis of Kefir}

As shown in Figure 3, the syneresis of kefir samples increased during the 21 days of storage at $4{ }^{\circ} \mathrm{C}$. Previous research has also shown an increase of syneresis in other fermented dairy products such as soymilk kefir and yoghurt during storage [35,36]. In this study, the syneresis of KG samples ranged from 25.71 to 30.12 , and hence a greater whey separation than KS samples, whose syneresis values ranged from 23.50 to 28.50 at 7,14 , and 21 days at $4{ }^{\circ} \mathrm{C}(p>0.05)$. These results are in agreement with Montanuci et al. [37], who reported greater syneresis of a formulation fermented with kefir grain compared to the formulation fermented with starter culture [37]. Our finding revealed that the syneresis of two formulations containing probiotic bacteria (KS-LGG and KG-LGG) was lower than the kefir samples made without LGG probiotic strain (KS and KG) at 7, 14, and 21 days of refrigerated storage $(p>0.05)$. However, the syneresis of KS-LGG and KG-LGG was higher than $\mathrm{KS}$ and $\mathrm{KG}$, respectively, after the first storage day at $4{ }^{\circ} \mathrm{C}$. One explanation for this result may be a decrease in $\mathrm{pH}$ during fermentation that enhances the resistance of casein particles to syneresis [38]. 

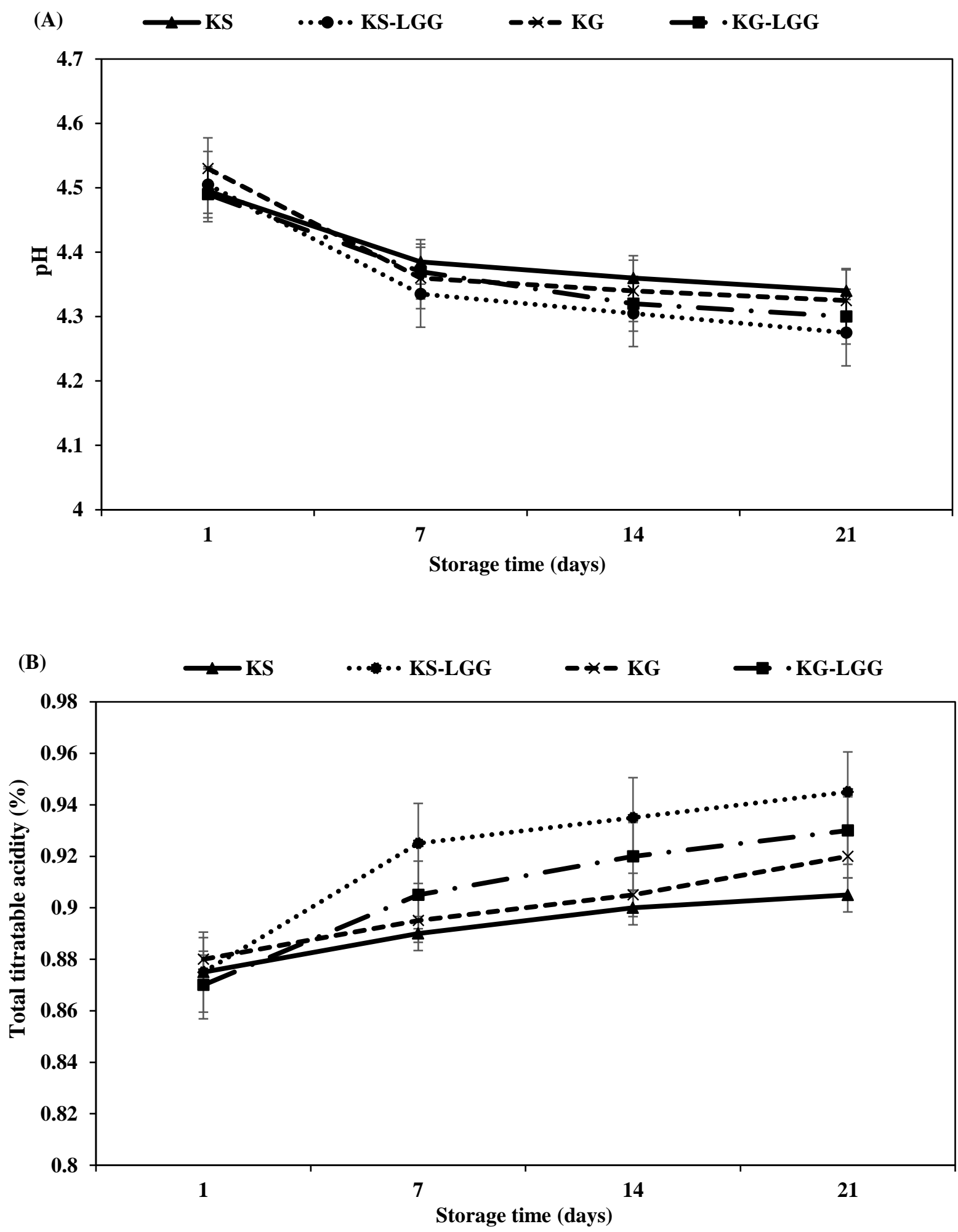

Figure 2. $\mathrm{pH}(\mathbf{A})$ and total titratable acidity (as lactic acid \%) (B) of different formulations of kefir during storage at $4{ }^{\circ} \mathrm{C}$. KG $=$ kefir produced from kefir grains, KG-LGG = kefir produced from kefir grains containing LGG, KS = kefir produced from natural kefir starter culture, and KS-LGG = kefir produced from natural kefir starter culture containing LGG. Error bars represent the mean $(n=3) \pm$ standard deviation (SD). 


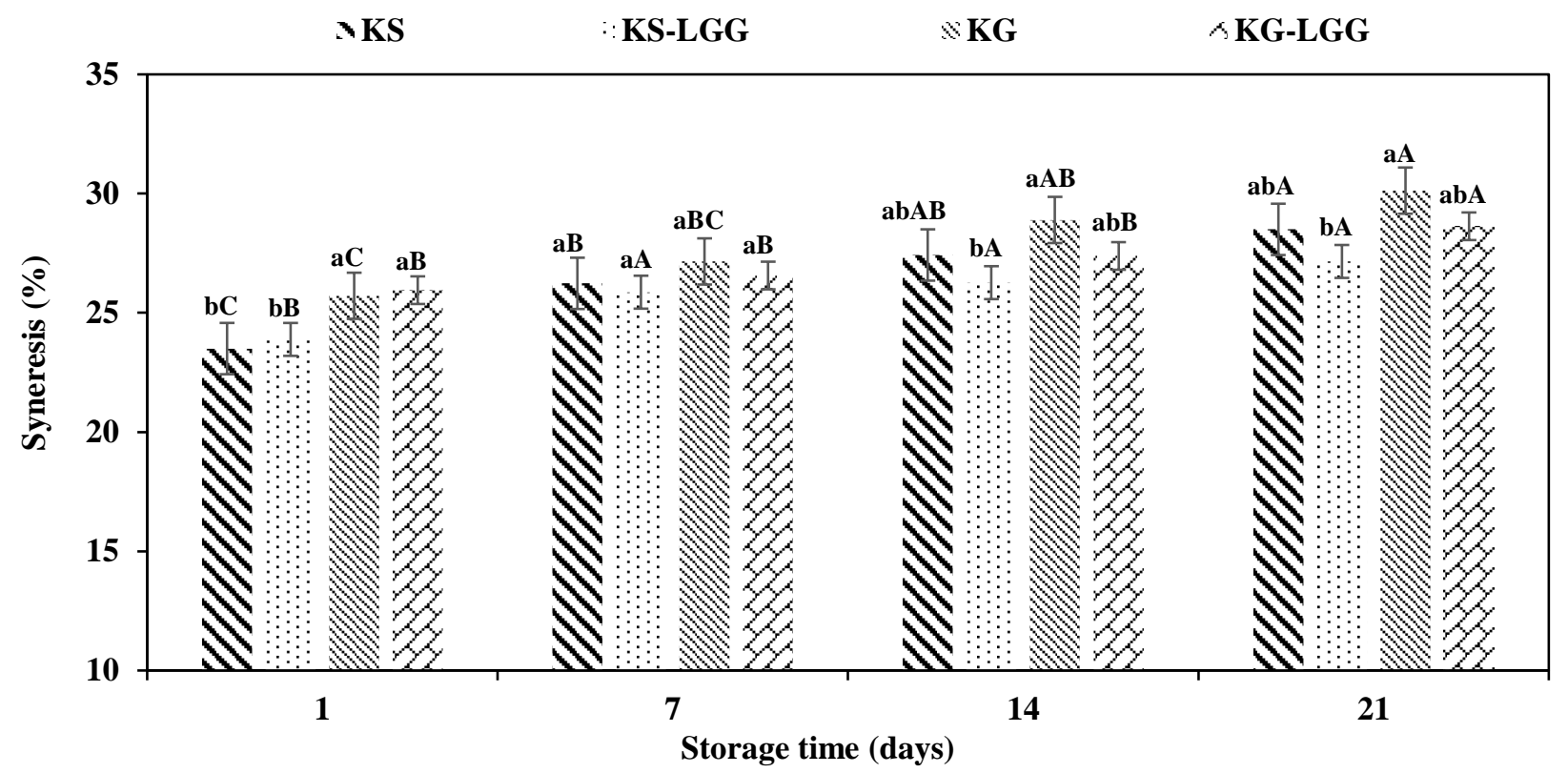

Figure 3. Syneresis (\%) of different formulations of kefir during storage at $4{ }^{\circ} \mathrm{C}$. $\mathrm{KG}=$ kefir produced from kefir grains, KG-LGG = kefir produced from kefir grains containing LGG, KS = kefir produced from natural kefir starter culture, and KS-LGG = kefir produced from natural kefir starter culture containing LGG. Lowercase letters indicate significant differences $(p<0.05)$ between samples at the same storage timepoint; uppercase letters indicate significant differences $(p<0.05)$ between the storage days of each kefir sample. Error bars represent the mean $(n=3) \pm$ standard deviation (SD).

KS-LGG products showed a slight decrease in syneresis compared with KG-LGG, which may be associated with $\mathrm{pH}$ and lactic acid \% [39,40]. Interestingly, we found that the syneresis values of KS-LGG and KG-LGG products showed significant differences only on day 1 of storage $(p<0.05)$. However, on days 7,14 , and 21 of the storage period, KS-LGG exhibited lower whey separation than KG-LGG. Several factors can contribute to this parameter, such as accumulation of organic acids, post-acidification [37], kefir concentration [41], kefiran concentration [42], total solid, and milk composition [43].

\subsection{Viability of LGG during Kefir Storage}

The survival of LGG bacteria in kefir beverages made with kefir grain as a carrier has already been reported [33]. However, no studies have confirmed this finding using natural kefir starter culture as a potential probiotic carrier in KS-LGG cocktail. It is generally demonstrated that the beneficial effect of probiotic bacteria in the gut environment depends on their population at a minimum level, which means that dairy products marketed as fermented probiotics should contain at least $10^{7} \mathrm{cfu} / \mathrm{mL}$ of viable probiotic cells [21,44].

In the current research, the viability of LGG bacteria in kefir grains and natural kefir starter culture was studied during a storage time of 21 days at $4{ }^{\circ} \mathrm{C}$ (Figure 4 and Supplementary Figure S1). After the first storage day at $4{ }^{\circ} \mathrm{C}$, LGG counts of KS-LGG and KG-LGG samples were 7.80 and $7.85 \mathrm{log} \mathrm{cfu} / \mathrm{mL}$, respectively (Figure 4). It should be noted that the LGG counts in KS-LGG and KG-LGG steadily increased up to 7 days of storage. Accordingly, the highest LGG counts were observed in different formulations of KS-LGG and KG-LGG after one week. At this point, the LGG counts of KS-LGG samples were significantly higher than in the KG-LGG samples (8.89 and $8.56 \log \mathrm{cfu} / \mathrm{mL}$, respectively) $(p<0.05$; Figure 4$)$. These results agree with the LGG counts reported in the literature: LGG in combination with kefir grain increased to $7.45 \mathrm{log} \mathrm{cfu} / \mathrm{g}$ until 6 days of storage [33]. Generally, kefir contains a diverse bacterial population; cell counts reportedly range between from 4.80 to $8.92 \log \mathrm{cfu} / \mathrm{mL}$ [45]. Bacteria such as LAB and lactobacilli as proteolytic organisms are capable of degrading milk proteins into smaller peptides and amino acids [46]. 
It is commonly recognized that LGG bacteria do not effectively degrade $\beta$-casein, but can hydrolyze $\alpha_{\mathrm{s} 1}$-casein $[27,47]$. Hence, LGG bacteria can utilize casein-derived peptides and amino acids for growth [47]. In accordance with our LGG counts after 7 days of storage, [48] similarly reported that L. rhamnosus bacteria viability ranged between 8 and $9 \log \mathrm{cfu} / \mathrm{mL}$ in casein hydrolysate and milk protein samples, respectively [48]. It was later shown that after 7 days of product fermentation at $4{ }^{\circ} \mathrm{C}$, LGG viability was between 7 and $8 \log \mathrm{cfu} / \mathrm{mL}$ in co-culture with Streptococcus thermophilus [49]. In contrast to our findings, [50] reported that the viability of LGG decreased from 6.88 to $6.70 \log \mathrm{cfu} / \mathrm{mL}$ in a cocktail culture with S. thermophilus, Lactobacillus acidophilus, Lactobacillus bulgaricus, and Bifidobacterium lactis from days 1 to 7 at $4{ }^{\circ} \mathrm{C}[50]$.

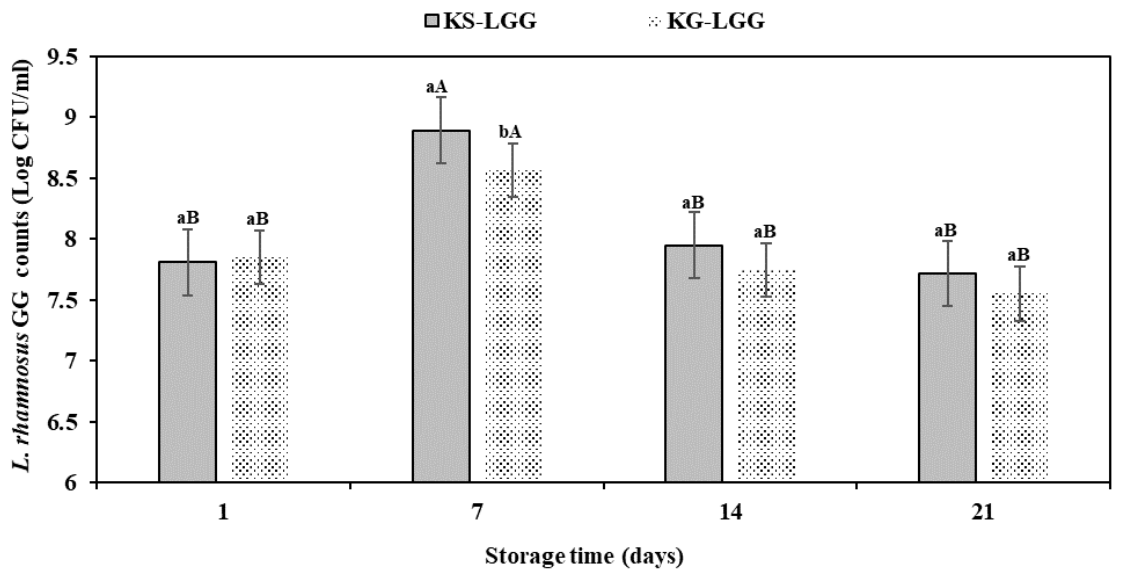

Figure 4. Viability of LGG in different formulations of kefir during storage at $4{ }^{\circ} \mathrm{C}$. $\mathrm{KG}=$ kefir produced from kefir grains, KG-LGG = kefir produced from kefir grains containing LGG, KS = kefir produced from natural kefir starter culture, and KS-LGG = kefir produced from natural kefir starter culture containing LGG. Lowercase letters indicate significant differences $(p<0.05)$ between samples at the same storage timepoints; uppercase letters indicate significant differences $(p<0.05)$ between the storage days of each kefir sample. Error bars represent the mean $(n=3) \pm$ standard deviation (SD).

After 7 days of storage, LGG counts gradually declined until 21 days of storage $(p<0.05)$, where the LGG final counts in KS-LGG and KG-LGG samples reached 7.71 and $7.55 \log \mathrm{cfu} / \mathrm{mL}$, respectively (Figure 4 ). On days 14 and 21 of storage, LGG counts were similar between KS-LGG and KG-LGG samples $(p>0.05)$. It is assumed that $\mathrm{pH}$ decline and post-acidification during storage of kefir samples (Figure 2) may lead to an adverse effect on the survival rate of probiotic bacteria $[7,31]$.

\subsection{Sensory Acceptance of Kefir}

A high-quality kefir beverage should have a satisfying flavor and high-grade maintenance properties [6,51]. The scores collected for flavor, body and texture, color and appearance, and overall acceptability of kefir samples with and without LGG bacteria are presented in Table 1. The flavor score of KS samples was significantly higher $(p<0.05)$ than KS-LGG, KG, and KG-LGG samples, indicating that lower acidity and yeasty flavor in natural kefir starter culture was preferred by the evaluators (Table 1). The superior flavor of KS may likely be associated with lower acidity in comparison to the other kefir samples, which is evident from the $\mathrm{pH}$ and TTA parameters (Figure 2). On the other hand, yeasty flavor and higher acidity may cause the lower flavor score in the KS-LGG samples; KS-LGG and KG-LGG samples were evaluated to have the lowest flavor scores. In line with our findings, Mitra and Ghosh [33] reported a similar observation in kefir grains with an LGG-enriched formula. In another study, probiotic yoghurt samples containing Lactobacillus reuteri and L. rhamnosus bacteria also received lower flavor scores [52]. It should be noted that LGG bacteria can produce a variety of organic acids such as lactic acid, pyruvic acid, orotic acid, succinic acid, and uric acid that may affect the flavor score. Some researchers reported that the probiotic LGG bacteria produced pyruvic acid, orotic acid, succinic acid, and uric acid 
in probiotic fermented milk $[53,54]$. In the current study, organic acids produced by LGG bacteria likely affected flavor scores in KS-LGG and KG-LGG samples.

Table 1. Sensory scores of kefirs with different formulations.

\begin{tabular}{ccccc}
\hline \multirow{2}{*}{$\begin{array}{c}\text { Kefir } \\
\text { Formulations }\end{array}$} & \multicolumn{4}{c}{ Sensory Attributes } \\
\cline { 2 - 5 } & Flavor & $\begin{array}{c}\text { Body and } \\
\text { Texture }\end{array}$ & $\begin{array}{c}\text { Color and } \\
\text { Appearance }\end{array}$ & $\begin{array}{c}\text { Overall } \\
\text { Acceptability }\end{array}$ \\
\hline KS & $4.46 \pm 0.63^{\mathrm{a}}$ & $4.20 \pm 0.84^{\mathrm{a}}$ & $4.00 \pm 0.84^{\mathrm{a}}$ & $4.26 \pm 0.45^{\mathrm{a}}$ \\
KS-LGG & $3.20 \pm 0.67^{\mathrm{b}}$ & $3.93 \pm 1.09^{\mathrm{a}}$ & $4.33 \pm 0.61^{\mathrm{a}}$ & $3.80 \pm 0.86^{\mathrm{a}}$ \\
KG & $3.60 \pm 0.82^{\mathrm{b}}$ & $4.26 \pm 0.70^{\mathrm{a}}$ & $4.40 \pm 0.84^{\mathrm{a}}$ & $3.86 \pm 0.51^{\mathrm{a}}$ \\
KG-LGG & $3.20 \pm 0.73^{\mathrm{b}}$ & $4.06 \pm 0.79^{\mathrm{a}}$ & $4.00 \pm 0.77^{\mathrm{a}}$ & $4.06 \pm 0.70^{\mathrm{a}}$ \\
\hline
\end{tabular}

a-b Values (average \pm SD) in the same column with the same lowercase letter are not significantly different $(p>0.05) .{ }^{1}$ Abbreviations of different kefir formulations: KG = kefir produced from kefir grains, KG-LGG = kefir produced from kefir grains containing LGG, KS = kefir produced from natural kefir starter culture, and KS-LGG = kefir produced from natural kefir starter culture co containing LGG.

All the kefir formulations received similar scores for body and texture $(p>0.05)$, although these scores for KS-LGG and KG-LGG samples were lower than those for KS and KG samples. The differences in body and texture could be associated with lower amounts of exopolysaccharide produced by the probiotic LGG bacteria compared to kefiran's biosynthesis by the microorganisms present in kefir [42,55]. As both the probiotic kefirs (KS-LGG and KG-LGG) appeared to have creamy consistency, and were both white and viscous, the color and appearance of the products did not differ significantly $(p>0.05)$. Notably, sieving the grains by cloth did not result in significant differences in body and texture scores. Similarly, there were no differences in color and appearance across the kefir formulations $(p>0.05)$. The same result was found for overall acceptability among the samples $(p>0.05)$. Several authors have investigated the effect of adding probiotic bacteria on sensory attributes in various fermented dairy products. For example, Ghaderi-Ghahfarokhi et al. [31] reported that the addition of Lacticaseibacillus casei strain into yoghurt did not produce any significant differences $(p>0.05)$ in appearance, body and texture, and overall acceptability compared to control samples. In another study, a camembert-type cheese enriched with Lacticaseibacillus rhamnosus GG was more acceptable than the control cheese, although these differences were not significant [56].

\subsection{Rheological Characteristics of Kefir}

Viscosity, hysteresis loop, and dynamic moduli indexes of kefir samples prepared with different formulations are presented in Tables 1-3, respectively. The hysteresis loop is considered as a reversible, isothermal, time-dependent decrease in the apparent viscosity when a material is subjected to increased shear rate [57]. The viscosity of the kefir samples ranged between $1197.1 \pm 50.2$ to $1269.6 \pm 173.7 \mathrm{mPa} \cdot \mathrm{s}$ on day 1 at $4{ }^{\circ} \mathrm{C}$ (Table 1 ). At first, the viscosity parameter seemed to be independent of fermentation, type of starter, and addition of probiotic bacteria. As shown in Table 2, KS samples had a higher viscosity than other kefir samples after the first day of storage. Similarly, Kök-Taş et al. [11] reported that the viscosity of kefir made with natural kefir starter culture was higher than that made with kefir grains on day 1 of cold storage. The decrease of viscosity with the increase of the shear rate suggests pseudoplastic behavior. One possibility is that sieving kefir grains after fermentation prohibited the formation of the gel network, which could affect the viscosity [37,58]. Similar observations were reported in other studies [11,26]. Unlike our findings, Mitra and Ghosh [33] reported a lower apparent viscosity of kefir prepared with starter compared to kefir produced by kefir grain. We found that unlike KS-LGG samples, the viscosity of KG-LGG samples was higher than that of the control kefir $(\mathrm{KG})(p>0.05)$ after day 1 of storage. 
Table 2. Viscosity (mPa.s) of kefir samples at $23.51 / \mathrm{s}$ shear rate.

\begin{tabular}{|c|c|c|c|c|}
\hline \multirow{2}{*}{$\begin{array}{c}\text { Kefir } \\
\text { Formulations }{ }^{1}\end{array}$} & \multicolumn{4}{|c|}{ Storage Period (d) } \\
\hline & 1 & 7 & 14 & 21 \\
\hline KS & $1269.6 \pm 173.7^{\mathrm{a}, \mathrm{A}}$ & $1300.0 \pm 0.0^{\mathrm{a}, \mathrm{A}}$ & $1340.0 \pm 28.3^{\mathrm{a}, \mathrm{A}}$ & $1345.0 \pm 7.1^{\mathrm{a}, \mathrm{A}}$ \\
\hline KS-LGG & $1225.8 \pm 6.2^{\mathrm{a}, \mathrm{A}}$ & $1315.0 \pm 7.1^{\mathrm{a}, \mathrm{A}}$ & $1175.0 \pm 120.2^{\mathrm{a}, \mathrm{A}}$ & $1250.0 \pm 56.6^{\mathrm{a}, \mathrm{A}}$ \\
\hline KG & $1197.1 \pm 50.2^{\mathrm{a}, \mathrm{A}}$ & $1225.0 \pm 77.8^{\mathrm{a}, \mathrm{A}}$ & $1240.0 \pm 56.6^{\mathrm{a}, \mathrm{A}}$ & $1200.0 \pm 0.0^{\mathrm{a}, \mathrm{A}}$ \\
\hline KG-LGG & $1262.9 \pm 25.5^{\mathrm{a}, \mathrm{A}}$ & $1360 \pm 56.6^{\mathrm{a}, \mathrm{A}}$ & $1275 \pm 49.5^{\mathrm{a}, \mathrm{A}}$ & $1260 \pm 14.4^{\mathrm{a}, \mathrm{A}}$ \\
\hline
\end{tabular}

a Values (average \pm SD) in the same column with the same superscript letters are not significantly different $(p>0.05) .{ }^{A}$ Values (average $\pm \mathrm{SD}$ ) in the same row with the same superscript letters are not significantly different $(p>0.05)$ between the storage days of each kefir sample. ${ }^{1}$ Abbreviations of different kefir formulations: KG = kefir produced from kefir grains, KG-LGG = kefir produced from kefir grains containing LGG, KS = kefir produced from natural kefir starter culture, and KS-LGG = kefir produced from natural kefir starter culture containing LGG $(n=2)$.

Table 3. Hysteresis loop area Pa/s of kefir samples between upper and lower area of the flow curves.

\begin{tabular}{ccccc}
\hline \multirow{2}{*}{$\begin{array}{c}\text { Kefir } \\
\text { Formulations }^{\mathbf{1}}\end{array}$} & $\mathbf{4}$ & $\mathbf{4}$ & $\mathbf{2 1}$ \\
\cline { 2 - 5 } & $\mathbf{1}$ & $\mathbf{7}$ & $\mathbf{1 4}$ & \\
\hline KS & $3094.5 \pm 481.5^{\mathrm{a}, \mathrm{A}}$ & $3116.5 \pm 30.4^{\mathrm{a}, \mathrm{A}}$ & $3067.5 \pm 152.0^{\mathrm{a}, \mathrm{A}}$ & $3075.5 \pm 0.7^{\mathrm{a}, \mathrm{A}}$ \\
KS-LGG & $3010 \pm 42.4^{\mathrm{a}, \mathrm{A}}$ & $3160.5 \pm 29.0^{\mathrm{a}, \mathrm{A}}$ & $2667 \pm 272.9^{\mathrm{a}, \mathrm{A}}$ & $2834 \pm 183.8^{\mathrm{a}, \mathrm{A}}$ \\
KG & $2646 \pm 152.7^{\mathrm{a}, \mathrm{A}}$ & $2592.5 \pm 191.6^{\mathrm{a}, \mathrm{A}}$ & $2657 \pm 161.2^{\mathrm{a}, \mathrm{A}}$ & $2520 \pm 19.8^{\mathrm{a}, \mathrm{A}}$ \\
KG-LGG $^{\mathrm{a}}$ & $2975.5 \pm 40.3^{\mathrm{a}, \mathrm{A}}$ & $3186.5 \pm 180.3^{\mathrm{a}, \mathrm{A}}$ & $2925 \pm 100.4^{\mathrm{a}, \mathrm{A}}$ & $2837.5 \pm 57.3^{\mathrm{a}, \mathrm{A}}$ \\
\hline
\end{tabular}

a Values (average \pm SD) in the same column with the same superscript letters are not significantly different $(p>0.05) .{ }^{A}$ Values (average $\left.\pm \mathrm{SD}\right)$ in the same row with the same superscript letters are not significantly different $(p>0.05)$ between the storage days of each kefir sample. ${ }^{1}$ Abbreviations of different kefir formulations: KG $=$ kefir produced from kefir grains, KG-LGG = kefir produced from kefir grains containing LGG, KS = kefir produced from natural kefir starter culture, and KS-LGG = kefir produced from natural kefir starter culture containing LGG $(n=2)$.

As presented in Tables 2-4, the indexes of viscosity, hysteresis loop, and dynamic moduli were similar across the various formulations of kefir, indicating that kefir products were similar in appearance and mouth-feel regardless of whether they were made with kefir grain or starter culture. These levels remained the same during 21 days of storage. Moreover, the results showed that the viscosity of kefir products correlated well with their thixotropic behavior, which is a significant issue in hydrogel rheological properties. The return of the hydrogel to its initial structure, known as hysteresis loop, was evaluated by observing the viscosity change during the restoration process after shearing $[59,60]$.

Table 4. Storage modulus $G^{\prime}$, loss modulus $G^{\prime \prime}$, and loss tangent $\left(\tan \delta=G^{\prime \prime} / G^{\prime}\right)$ of kefir samples at frequency of $1.46 \mathrm{~Hz}$.

\begin{tabular}{|c|c|c|c|c|c|c|c|c|c|c|c|c|}
\hline \multirow{3}{*}{$\begin{array}{l}\text { Kefir } \\
\text { Formula- } \\
\text { tions } \\
1\end{array}$} & \multicolumn{12}{|c|}{ Storage Period (d) } \\
\hline & \multicolumn{3}{|c|}{ d 1} & \multicolumn{3}{|c|}{ d 7} & \multicolumn{3}{|c|}{ d 14} & \multicolumn{3}{|c|}{ d 21} \\
\hline & $\mathrm{G}^{\prime}$ & $\mathrm{G}^{\prime \prime}$ & $\tan (\delta)$ & $\mathrm{G}^{\prime}$ & $\mathrm{G}^{\prime \prime}$ & $\tan (\delta)$ & $\mathrm{G}^{\prime}$ & $\mathrm{G}^{\prime \prime}$ & $\tan (\delta)$ & $\mathrm{G}^{\prime}$ & $\mathrm{G}^{\prime \prime}$ & $\tan (\delta)$ \\
\hline KS & $\begin{array}{l}200.6 \pm \\
73.4^{\mathrm{a}, \mathrm{A}}\end{array}$ & $\begin{array}{l}53.5 \pm \\
20.0^{\mathrm{a}, \mathrm{A}}\end{array}$ & $\begin{array}{c}0.266 \pm \\
0.002^{\mathrm{a}, \mathrm{A}}\end{array}$ & $\begin{array}{c}177.4 \pm \\
5.7^{\mathrm{a}, \mathrm{A}}\end{array}$ & $\begin{array}{l}44.2 \pm \\
1.0^{\mathrm{a}, \mathrm{A}}\end{array}$ & $\begin{array}{c}0.249 \pm \\
0.019 \mathrm{a}, \mathrm{A}\end{array}$ & $\begin{array}{l}181.8 \pm \\
1.27^{\mathrm{a}, \mathrm{A}}\end{array}$ & $\begin{array}{l}46.2 \pm \\
2.6^{\mathrm{a}, \mathrm{A}}\end{array}$ & $\begin{array}{c}0.254 \pm \\
0.012^{\mathrm{a}, \mathrm{A}}\end{array}$ & $\begin{array}{l}190.3 \pm \\
24.0^{\mathrm{a}, \mathrm{A}}\end{array}$ & $\begin{array}{c}46.4 \\
\pm 5.6^{\mathrm{a}, \mathrm{A}}\end{array}$ & $\begin{array}{c}0.244 \pm \\
0.001^{\mathrm{a}, \mathrm{A}}\end{array}$ \\
\hline KS-LGG & $\begin{array}{l}156.8^{\mathrm{a}} \pm \\
12.2^{\mathrm{A}}\end{array}$ & $\begin{array}{l}42.3 \pm \\
1.80^{\mathrm{a}, \mathrm{A}}\end{array}$ & $\begin{array}{c}0.270 \pm \\
0.009^{\mathrm{a}, \mathrm{A}}\end{array}$ & $\begin{array}{l}176.5 \pm \\
17.3^{\mathrm{a}, \mathrm{A}}\end{array}$ & $\begin{array}{l}46.2 \pm \\
1.6^{\mathrm{a}, \mathrm{A}}\end{array}$ & $\begin{array}{c}0.262 \pm \\
0.016^{\mathrm{a}, \mathrm{A}}\end{array}$ & $\begin{array}{l}171.1 \pm \\
17.8^{\mathrm{a}, \mathrm{A}}\end{array}$ & $\begin{array}{l}43.4 \pm \\
1.5^{\mathrm{a}, \mathrm{A}}\end{array}$ & $\begin{array}{c}0.254 \pm \\
0.017^{\mathrm{a}, \mathrm{A}}\end{array}$ & $\begin{array}{c}160.3 \pm \\
9.0^{\mathrm{a}, \mathrm{A}}\end{array}$ & $\begin{array}{l}42.3 \pm \\
1.3^{\mathrm{a}, \mathrm{A}}\end{array}$ & $\begin{array}{c}0.253 \pm \\
0.005^{\mathrm{a}, \mathrm{A}}\end{array}$ \\
\hline KG & $\begin{array}{c}146.6 \pm \\
0.1^{\mathrm{a}, \mathrm{A}}\end{array}$ & $\begin{array}{l}40.3 \pm \\
3.1 \mathrm{a}, \mathrm{A}\end{array}$ & $\begin{array}{c}0.274 \pm \\
0.021^{\mathrm{a}, \mathrm{A}}\end{array}$ & $\begin{array}{l}186.9 \pm \\
31.3^{\mathrm{a}, \mathrm{A}}\end{array}$ & $\begin{array}{l}46.8 \pm \\
8.5^{\mathrm{a}, \mathrm{A}}\end{array}$ & $\begin{array}{c}0.250 \pm \\
0.003^{\mathrm{a}, \mathrm{A}}\end{array}$ & $\begin{array}{l}153.0 \pm \\
28.2^{\mathrm{a}, \mathrm{A}}\end{array}$ & $\begin{array}{l}38.3 \pm \\
7.8^{\mathrm{a}, \mathrm{A}}\end{array}$ & $\begin{array}{c}0.249 \pm \\
0.005^{\mathrm{a}, \mathrm{A}}\end{array}$ & $\begin{array}{c}119.3 \pm \\
7.4 \mathrm{a}, \mathrm{A}\end{array}$ & $\begin{array}{l}30.1 \pm \\
0.7^{\mathrm{a}, \mathrm{A}}\end{array}$ & $\begin{array}{l}0.252 \pm \\
0.009^{\mathrm{a}, \mathrm{A}}\end{array}$ \\
\hline KG-LGG & $\begin{array}{c}203.8 \pm \\
2.3^{\mathrm{a}, \mathrm{A}}\end{array}$ & $\begin{array}{l}53.7 \pm \\
0.1^{\mathrm{a}, \mathrm{A}}\end{array}$ & $\begin{array}{c}0.263 \pm \\
0.002^{\mathrm{a}, \mathrm{A}}\end{array}$ & $\begin{array}{l}185.5 \pm \\
16.9^{\mathrm{a}, \mathrm{A}}\end{array}$ & $\begin{array}{l}46.0 \pm \\
4.3^{\mathrm{a}, \mathrm{A}}\end{array}$ & $\begin{array}{c}0.248 \pm \\
0.009 \mathrm{a}, \mathrm{A}\end{array}$ & $\begin{array}{l}143.1 \pm \\
11.0^{\mathrm{a}, \mathrm{A}}\end{array}$ & $\begin{array}{l}35.2 \pm \\
3.7^{\mathrm{a}, \mathrm{A}}\end{array}$ & $\begin{array}{c}0.246 \pm \\
0.007^{\mathrm{a}, \mathrm{A}}\end{array}$ & $\begin{array}{l}153.9 \pm \\
26.2^{\mathrm{a}, \mathrm{A}}\end{array}$ & $\begin{array}{l}36.9 \pm \\
0.0^{\mathrm{a}, \mathrm{A}}\end{array}$ & $\begin{array}{c}0.239 \pm \\
0.003^{\mathrm{a}, \mathrm{A}}\end{array}$ \\
\hline
\end{tabular}

${ }^{a}$ Values (average $\pm \mathrm{SD}$ ) in the same column with the same superscript letters are not significantly different $(p>0.05)$. A Values (average $\pm \mathrm{SD}$ ) in the same row with the same superscript letters are not significantly different $(p>0.05)$ between the storage days of each kefir sample. ${ }^{1}$ Abbreviations of different kefir formulations: KG $=$ kefir produced from kefir grains, KG-LGG = kefir produced from kefir grains containing LGG, KS = kefir produced from natural kefir starter culture, and KS-LGG = kefir produced from natural kefir starter culture containing LGG $(n=2)$.

In this study, the viscosity of KS and KG samples gradually increased during storage at $4{ }^{\circ} \mathrm{C}$, except for the decrease in viscosity in the KG sample at day 21 compared to the previous days of storage time. In agreement with our results, Beshkova et al. [61] 
reported that the viscosity of kefir made with pure culture and kefir grain increased after 7 days. Further, the hysteresis loop and viscosity of KS-LGG and KG-LGG samples were higher than $\mathrm{KS}$ and $\mathrm{KG}$, respectively, at 7 days of storage. It is reasonable to assume that an interaction between milk proteins and the extracellular polysaccharide, kefiran, may influence viscosity. Some studies at the molecular level showed that EPS materials could bind water, and the interaction of proteins may be associated with increased viscosity and thixotropic behavior in these products [59,62].

In the current study, the hysteresis loop, storage modulus $\left(G^{\prime}\right)$, loss modulus $\left(G^{\prime \prime}\right)$, and viscosity of KS-LGG samples were lower than KS samples, except at 7 days of storage. The storage modulus $G^{\prime}>$ loss modulus $G^{\prime \prime}$ suggested gel-like structure, while loss tangent $(\tan \delta)$ indicated the strength of the gel supported by the milk protein network and the production of exopolysaccharides. Combined with results from previous studies, these findings advance our understanding of the mechanisms of viscosity reduction by reduced EPS levels, which results from hydrolyzation of EPS into its monomers by glycohydrolases $[63,64]$. It has been reported [65] that the viscosity of EPS production by L. rhamnosus was reduced by glycohydrolases during cold storage. In this study, both storage $\left(\mathrm{G}^{\prime}\right)$ and loss $\left(\mathrm{G}^{\prime \prime}\right)$ modulus of KS-LGG were lower than KS during storage (Table 4). This decrease can be attributed to the hydrolyzation of EPS due to glycohydrolases and increased acidity (Figure 2) as compared with control kefir (KS) [66,67]. In other research, EPS produced by bacteria was recognized to interact with milk proteins and improve viscoelastic properties of weak gels such as yoghurt [68]. Therefore, we could expect that the decrease in EPS level may have reduced the viscosity values of the KS-LGG samples in our study. The reduced viscosity of KS-LGG compared to the control kefir (KS) could be related to sensory acceptance, as the evaluators voted for kefir with slightly thicker composition, which may result from more negligible EPS and increased acidity.

\section{Conclusions}

We manufactured kefir products from a variety of starting products, including kefir grains and natural kefir starter culture with and without probiotic LGG bacteria. LGGenriched natural kefir starter culture showed an average LGG count of $8.09 \mathrm{log} \mathrm{cfu} / \mathrm{mL}$ during 21 days of storage at $4{ }^{\circ} \mathrm{C}$. In addition to this benefit, in sensory analysis at 10 days of storage, although natural kefir starter culture achieved the highest overall acceptability score close to the maximum, other kefir products were evaluated as having satisfactory sensorial acceptance. Based on the rheological and the probiotic LGG bacteria viability observations during a period of refrigerated storage, we postulated that kefir with an LGG-enriched formula could potentially be used as a beverage, since the addition of LGG bacteria to natural kefir starter culture did not significantly affect the viscosity properties. Taken together, using natural kefir starter culture without grains is more convenient and applicable than retaining kefir grains in large-scale industrial production. As such, probiotic LGG bacteria could be a potential alternative to produce kefir with remedial efficacy in the dairy industry. However, further studies should be conducted to evaluate the microbial analysis and organic acid profile in kefir grain and natural kefir starter culture.

Supplementary Materials: The following supporting information can be downloaded at: https: / / www.mdpi.com/article/10.3390/foods11040523/s1, Figure S1: Amplification of Lacticaseibacillus rhamnosus GG DNA. Lane M is a 100-bp ladder. Lanes 1,2,6, represent positive samples. Lanes 3,4 represent negative samples. Lane 5 is a positive control with Lacticaseibacillus rhamnosus GG (ATCC 53103) DNA. Lane 7 is a negative control without DNA.

Author Contributions: Conceptualization, A.Y., P.E.J.S. and M.Z.; methodology, A.Y. and X.H.; software, A.Y. and X.H.; validation, A.Y.; formal analysis, A.Y. and X.H.; investigation, A.Y. and X.H.; resources P.E.J.S.; data curation, A.Y. and X.H.; writing-original draft preparation, A.Y.; writingreview and editing, A.Y., P.E.J.S., X.H. and M.Z.; visualization, A.Y. and P.E.J.S.; supervision, P.E.J.S.; project administration, P.E.J.S.; funding acquisition, P.E.J.S. All authors have read and agreed to the published version of the manuscript. 
Funding: Open access funding provided by University of Helsinki.

Institutional Review Board Statement: Not applicable.

Informed Consent Statement: Not applicable.

Data Availability Statement: All data related to the research are presented in the article.

Acknowledgments: The authors thank Shahid Chamran University of Ahvaz for financial support to the first author to complete this project at the University of Helsinki, Finland. The authors would also like to thank Tuula Sontag-Strohm (Department of Food and Nutrition, University of Helsinki) for providing access to the HAAKE MARS Rheometer facilities.

Conflicts of Interest: The authors declare no conflict of interest.

\section{References}

1. Ferreira, I.M.P.L.V.O.; Pinho, O.; Monteiro, D.; Faria, S.; Cruz, S.; Perreira, A.; Roque, A.C.; Tavares, P. Short communication: Effect of kefir grains on proteolysis of major milk proteins. J. Dairy Sci. 2010, 93, 27-31. [CrossRef] [PubMed]

2. Gul, O.; Mortas, M.; Atalar, I.; Dervisoglu, M.; Kahyaoglu, T. Manufacture and characterization of kefir made from cow and buffalo milk, using kefir grain and starter culture. J. Dairy Sci. 2015, 98, 1517-1525. [CrossRef] [PubMed]

3. Azi, F.; Tu, C.; Meng, L.; Zhiyu, L.; Cherinet, M.T.; Ahmadullah, Z.; Dong, M. Metabolite dynamics and phytochemistry of a soy whey-based beverage bio-transformed by water kefir consortium. Food Chem. 2021, 16, 128-225. [CrossRef] [PubMed]

4. $\quad$ Lynch, K.M.; Wilkinson, S.; Daenen, L.; Arendt, E.K. An update on water kefir: Microbiology, composition and production. Int. J. Food Microbiol. 2021, 345, 109-128. [CrossRef] [PubMed]

5. Gut, A.M.; Vasiljevic, T.; Yeager, T.; Donkor, O.N. Characterization of yeasts isolated from traditional kefir grains for potential probiotic properties. J. Funct. Foods 2019, 58, 56-66. [CrossRef]

6. Lopitz-Otsoa, F.; Rementeria, A.; Elguezabal, N.; Garaizar, J. Kefir: A symbiotic yeasts-bacteria community with alleged healthy capabilities. Rev. Iberoam Micol. 2006, 23, 67-74. [CrossRef]

7. Nejati, F.; Junne, S.; Neubauer, P. A big world in small grain: A review of natural milk kefir starters. Microorganisms 2020, 8, 192. [CrossRef]

8. Vardjan, T.; Mohar Lorb, P.; Rogelj, I.; Čanžek, M.A. Characterization and stability of lactobacilli and yeast microbiota in kefir grains. J. Dairy Sci. 2013, 96, 2729-2736. [CrossRef]

9. Gagliarini, N.; Diosma, G.; Garrote, G.L.; Abraham, A.G.; Piermaria, J. Whey protein-kefiran films as driver of probiotics to the gut. LWT 2019, 105, 321-328. [CrossRef]

10. Erdogan, F.S.; Ozarslan, S.; Guzel-Seydim, Z.B.; Kök Taş, T. The effect of kefir produced from natural kefir grains on the intestinal microbial populations and antioxidant capacities of Balb/c mice. Food Res. J. 2019, 115, 408-413. [CrossRef]

11. Kök-Taş, T.; Seydim, A.C.; Özer, B.; Guzel-Seydim, Z.B. Effects of different fermentation parameters on quality characteristics of kefir. J. Dairy Sci. 2013, 96, 780-789. [CrossRef] [PubMed]

12. Agarbati, A.; Ciani, M.; Canonico, L.; Galli, E.; Comitini, F. Exploitation of yeasts with probiotic traits for kefir production: Effectiveness of the microbial consortium. Fermentation 2022, 8, 9. [CrossRef]

13. Zendeboodi, F.; Khorshidian, N.; Mortazavian, A.M.; Cruz, A.G.D. Probiotic: Conceptualization from a new approach. Curr. Opin. Food Sci. 2020, 32, 103-123. [CrossRef]

14. Chugh, B.; Kamal-Eldin, A. Bioactive compounds produced by probiotics in food products. Curr. Opin. Food Sci. 2020, 32, 76-82 [CrossRef]

15. Mattila-Sandholm, T.; Blum, S.; Collins, J.K.; Crittenden, R.; de Vos, W.; Dunne, C.; Fondén, R.; Grenov, G.; Isolauri, E.; Kiely, B.; et al. Probiotics: Towards demonstrating efficacy. Trends Food Sci. Technol. 1999, 10, 393-399. [CrossRef]

16. Vimercati, W.C.; Araújo, C.D.S.; Macedo, L.L.; Fonseca, H.C.; Guimarães, J.S.; Abreu, L.R.D.; Pinto, S.M. Physicochemical, rheological, microbiological and sensory properties of newly developed coffee flavored kefir. LWT 2020, 123, 109069. [CrossRef]

17. Nyanzi, R.; Jooste, P.J.; Buys, E.M. Invited review: Probiotic yogurt quality criteria, regulatory framework, clinical evidence, and analytical aspects. Int. J. Dairy Sci. 2021, 104, 1-19. [CrossRef]

18. Buran, İ.; Akal, C.; Ozturkoglu-Budak, S.; Yetisemiyen, A. Rheological, sensorial and volatile profiles of synbiotic kefirs produced from cow and goat milk containing varied probiotics in combination with fructooligosaccharide. LWT 2021, 148, 111591. [CrossRef]

19. Oliveira, R.P.D.S.; Perego, P.; Oliveira, M.N.; Converti, A. Effect of inulin as a prebiotic to improve growth and counts of a probiotic cocktail in fermented skim milk. LWT 2011, 44, 520-523. [CrossRef]

20. Valik, L.; Medvedova, A.; Lipatkova, D. Characterization of the growth of Lactobacillus rhamnosus GG. J. Food Nutr. Res. 2008, 47, 60-67.

21. Innocente, N.; Biasutti, M.; Rita, F.; Brichese, R.; Comi, G.; Iacumin, L. Effect of indigenous Lactobacillus rhamnosus isolated from bovine milk on microbiological characteristics and aromatic profile of traditional yogurt. LWT 2016, 66, 158-164. [CrossRef]

22. Galli, B.D.; Baptista, D.P.; Cavalheiro, F.G.; Negrão, F.; Eberlin, M.N.; Gigante, M.L. Peptide profile of Camembert-type cheese: Effect of heat treatment and adjunct culture Lactobacillus rhamnosus GG. Int. Food Res. J. 2019, 123, 393-402. [CrossRef] [PubMed] 
23. Parker, M.; Zobrist, S.; Donahue, C.; Edick, C.; Mansen, K.; Nadjari, M.H.Z.; Heerikhuisen, M.; Sybesma, W.; Molenaar, D.; Diallo, A.M.; et al. Naturally fermented milk from northern Senegal: Bacterial community composition and probiotic enrichment with Lactobacillus rhamnosus. Front. Microbiol. 2018, 9, 2218. [CrossRef]

24. Ramírez-Godínez, J.; Gutiérrez-Rodríguez, J.F.; Contreras-López, E.; Rodríguez-Serrano, G.M.; Castañeda-Ovando, A.; JaimezOrdaz, J.; González-Olivares, L.G. Agave juice improves survival and proteolytic activity of Lactobacillus rhamnosus GG during ripening of semi-ripened mexican cheese. Food Sci. Technol. 2021, 2061, 6-11. [CrossRef]

25. Rodgers, S. Preserving non-fermented refrigerated foods with microbial cultures-A review. Trends Food Sci. Technol. 2001, 12, $276-284$. [CrossRef]

26. Irigoyen, A.; Arana, I.; Castiella, M.; Torre, P.; Ibáñez, F.C. Microbiological, physicochemical, and sensory characteristics of kefir during storage. Food Chem. 2005, 90, 613-620. [CrossRef]

27. Hussain, N.; Li, R.; Takala, T.M.; Tariq, M.; Zaidi, A.H.; Saris, P.E.J. Generation of lactose- and protease-positive probiotic Lacticaseibacillus rhamnosus GG by conjugation with Lactococcus lactis NCDO 712. Appl. Environ. Microbiol. 2021, 87, e02957-20. [CrossRef] [PubMed]

28. Horwitz, W.; Latimer, G.W. Official Methods of Analysis, 18th ed.; AOAC: Washington, DC, USA, $2005 ;$ p. 7.

29. Aryana, K.J.A.R. Folic acid fortified fat-free plain set yoghurt. Int. J. Dairy Technol. 2003, 56, 219-222. [CrossRef]

30. Mohammed, A.A.; Hussain, N.A.; Niamah, A.K. Antibacterial spectrum of produced reuterin from new isolates of Lactobacillus reuteri. J. Microbiol. Biotechnol. Food Sci. 2020, 10, 134-139. [CrossRef]

31. Ghaderi-Ghahfarokhi, M.; Yousefvand, A.; Ahmadi Gavlighi, H.; Zarei, M.; Farhangnia, P. Developing novel synbiotic low-fat yogurt with fucoxylogalacturonan from tragacanth gum: Investigation of quality parameters and Lactobacillus casei survival. Food Sci. Nutr. 2020, 8, 4491-4504. [CrossRef]

32. Karaca, O.B.; Güzeler, N.; Tangüler, H.; Yaşar, K.; Akın, M.B. Effects of apricot fibre on the physicochemical characteristics, the sensory properties and bacterial viability of nonfat probiotic yoghurts. Foods 2019, 8, 33. [CrossRef] [PubMed]

33. Mitra, S.; Ghosh, B.C. Quality characteristics of kefir as a carrier for probiotic Lactobacillus rhamnosus GG. Int. J. Dairy Technol. 2019, 70, 384-391. [CrossRef]

34. Collar, C. Review: Biochemical and technological assessment of the metabolism of pure and mixed cultures of yeast and lactic acid bacteria in breadmaking. Int. Food Sci. Technol. 1996, 2, 349-367. [CrossRef]

35. Kesenkas, H.; Ddnkcd, N.; Seckdn, K.; Kinik, Ö.; Gonc, S.; Ergonul, P.G.; Kavas, G.; Gökhan, A. Physicochemical, microbiological and sensory characteristics of Soymilk Kefir Harun. Afr. J. Microbiol. Res. 2011, 22, 3737-3746.

36. Sah, B.N.P.; Vasiljevic, T.; McKechnie, S.; Donkor, O.N. Physicochemical, textural and rheological properties of probiotic yogurt fortified with fibre-rich pineapple peel powder during refrigerated storage. LWT 2016, 65, 978-986. [CrossRef]

37. Montanuci, F.D.; Pimentel, T.C.; Garcia, S.; Prudencio, S.H. Effect of starter culture and inulin addition on microbial viability, texture, and chemical characteristics of whole or skim milk kefir. Food Sci. Technol. 2012, 32, 580-865. [CrossRef]

38. Öztürk, B.A.; Öner, M.D. Production and evaluation of yogurt with concentrated grape juice. J. Food Sci. 1999, 64, 530-532. [CrossRef]

39. Vogado, C.D.O.; Leandro, E.D.S.; Zandonadi, R.P.D.; Alencar, E.R.; Ginani, V.C.; Nakano, E.Y.; Habú, S.; Aguiar, P.A. Enrichment of probiotic fermented milk with green banana pulp: Characterization microbiological, physicochemical and sensory. Nutrients 2018, 10, 427. [CrossRef] [PubMed]

40. Yerlikaya, O.; Akpinar, A.; Saygili, D. Analysis of some physicochemical, rheological, sensorial properties, and probiotic viability of fermented milks containing Enterococcus faecium and Enterococcus durans strains. J. Food Process. Preserv. 2020, 44, e14553. [CrossRef]

41. Delgadillo, J.O.V.; Lara, M.D.J.L.; Santillan, C.K.L.; Sampieri, C.B.; Micloth, L.D.C.L. Physicochemical and rheological characterization of an acidic milk product: Kefir concentration effect. J. Food Eng. 2017, 7, 86-92.

42. Moradi, Z.; Kalanpour, N. Kefiran, a branched polysaccharide: Preparation, properties and applications: A review. Carbohyd. Polym. 2019, 223, 115100. [CrossRef] [PubMed]

43. Vareltzis, P.; Adamopoulos, K.; Stavrakakis, E.; Stefanakis, A.; Goula, A.M. Approaches to minimise yoghurt syneresis in simulated tzatziki sauce preparation. Int. J. Dairy Technol. 2016, 69, 191-199. [CrossRef]

44. Granato, D.; Branco, G.F.; Cruz, A.G.; de Assis Fonseca Faria, J.; Shah, N.P. Probiotic dairy products as functional foods. Compr. Rev. Food Sci. 2010, 9, 455-470. [CrossRef] [PubMed]

45. Witthuhn, R.C.; Schoeman, T.; Britz, T.J. Isolation and characterization of the microbial population of different South African kefir grains. Int. J. Dairy Technol. 2004, 57, 33-37. [CrossRef]

46. Saxelin, M. Lactobacillus GG-A human probiotic strain with thorough clinical documentation. Food Rev. Int. 1997, 13, 293-313. [CrossRef]

47. Savijoki, K.; Nyman, T.A.; Kainulainen, V.; Miettinen, I.; Siljamäki, P.; Fallarero, A.; Sandholm, J.; Satokari, R.; Varmanen, P. Growth mode and carbon source impact the surfaceome dynamics of Lactobacillus rhamnosus GG. Front. Microbiol. 2019, 10, 1272. [CrossRef]

48. Oliveira, M.N.; Sodini, I.; Remeuf, F.; Corrieu, G. Effect of milk supplementation and culture composition on acidification, textural properties and microbiological stability of fermented milks containing probiotic bacteria. Int. Dairy J. 2001, 11, 935-942. [CrossRef]

49. Oliveira, R.P.D.S.; Perego, P.; Converti, A.; Oliveira, M.N. The effect of inulin as a prebiotic on the production of probiotic fibre-enriched fermented milk. Int. J. Dairy Technol. 2009, 62, 195-203. [CrossRef] 
50. Oliveira, R.P.D.S.; Perego, P.; Oliveira, M.N.; Converti, A. Effect of inulin on the growth and metabolism of a probiotic strain of Lactobacillus rhamnosus in co-culture with Streptococcus thermophilus. LWT 2012, 47, 358-363. [CrossRef]

51. Leite, A.M.D.O.; Miguel, M.A.L.; Peixoto, R.S.; Rosado, A.S.; Silva, J.T.; Paschoalin, V.M.F. Microbiological, technological and therapeutic properties of kefir: A natural probiotic beverage. Braz. J. Microbiol. 2013, 349, 341-349. [CrossRef]

52. Hekmat, S.; Reid, G. Sensory properties of probiotic yogurt is comparable to standard yogurt. Nutr. Res. 2006, 26, 163-166. [CrossRef]

53. Østlie, H.M.; Helland, M.H.; Narvhus, J.A. Growth and metabolism of selected strains of probiotic bacteria in milk. Int. J. Food Microbiol. 2003, 15, 17-27. [CrossRef]

54. Østlie, H.M.; Treimo, J.; Narvhus, J.A. Effect of temperature on growth and metabolism of probiotic bacteria in milk. Int. Dairy J. 2005, 15, 989-997. [CrossRef]

55. Kiekens, S.; Vandenheuvel, D.; Broeckx, G.; Claes, I.; Allonsius, C.; De Boeck, I.; Thys, S.; Timmermans, J.P.; Kiekens, F.; Lebeer, S. Impact of spray-drying on the pili of Lactobacillus rhamnosus GG. Microb. Biotechnol. 2019, 12, 849-855. [CrossRef]

56. Galli, B.D.; Baptista, D.P.; Cavalheiro, F.G.; Gigante, M.L. Lactobacillus rhamnosus GG improves the sensorial profile of Camemberttype cheese: An approach through flash-profile and CATA. LWT 2019, 107, 72-78. [CrossRef]

57. Mewis, J.; Wagner, N.J. Thixotropy. Adv. Colloid Interface Sci. 2009, 147-148, 214-227. [CrossRef]

58. Barukčić, I.; Gracin, L.; Jambrak, A.R.; Božanić, R. Comparison of chemical, rheological and sensory properties of kefir produced by kefir grains and commercial kefir starter. Mljekarstvo 2017, 67, 169-176. [CrossRef]

59. Ghica, M.V.; Hîrjău, M.; Lupuleasa, D.; Dinu-Pîrvu, C.E. Flow and thixotropic parameters for rheological characterization of hydrogels. Molecules 2016, 21, 786. [CrossRef]

60. Hoshizawa, H.; Minemura, Y.; Yoshikawa, K.; Suzuki, M.; Hanabusa, K. Thixotropic hydrogelators based on a cyclo(dipeptide) derivative. Langmuir 2013, 29, 14666-14673. [CrossRef]

61. Beshkova, D.M.; Simova, E.D.; Simov, Z.I.; Frengova, G.I.; Spasov, Z.N. Pure cultures for making kefir. Food Microbiol. 2002, 19 , 537-544. [CrossRef]

62. Amatayakul, T.; Halmos, A.L.; Sherkat, F.; Shah, N.P. Physical characteristics of yoghurts made using exopolysaccharideproducing starter cultures and varying casein to whey protein ratios. Int. Dairy J. 2006, 16, 40-51. [CrossRef]

63. Degeest, B.; Mozzi, F.; De Vuyst, L. Effect of medium composition and temperature and pH changes on exopolysaccharide yields and stability during Streptococcus thermophilus LY03 fermentations. Int. J. Food Microbiol. 2002, 79, 161-174. [CrossRef]

64. Purwandari, U.; Shah, N.P.; Vasiljevic, T. Effects of exopolysaccharide-producing strains of Streptococcus thermophilus on technological and rheological properties of set-type yoghurt. Int. Dairy J. 2007, 17, 1344-1352. [CrossRef]

65. Pham, P.L.; Dupont, I.; Roy, D.; Lapointe, G.; Cerning, J. Production of exopolysaccharide by Lactobacillus rhamnosus R and analysis of its enzymatic degradation during prolonged fermentation. Appl. Environ. Microbiol. 2000, 66, 2302-2310. [CrossRef] [PubMed]

66. Bensmira, M.; Jiang, B. Effect of some operating variables on the microstructure and physical properties of a novel kefir formulation. J. Food Eng. 2012, 108, 579-584. [CrossRef]

67. Vlahopoulou, I.; Bell, A.E. Effect of various starter cultures on the viscoelastic properties of bovine and caprine yogurt gels. J. Soc. Dairy Technol. 1993, 46, 61-63. [CrossRef]

68. Vlahopoulou, I.; Bell, A.E.; Wilbey, R. Effects of starter culture and its exopolysaccharides on the gelation of glucono- $\delta$-lactoneacidified bovine and caprine milk. Int. J. Dairy Technol. 2001, 54, 135-140. [CrossRef] 